\title{
ANALISIS EFEKTIVITAS PROGRAM REVITALISASI PASAR TRADISIONAL DAN DAMPAKNYA TERHADAP PENDAPATAN PEDAGANG DAN PENGELOLAAN PASAR POHGADING
}

\author{
Kadek Cyntia Pratiwi ${ }^{1}$ \\ I Nengah Kartika ${ }^{2}$ \\ ${ }^{1,2}$ Fakultas Ekonomi dan Bisnis Universitas Udayana (Unud), Bali, Indonesia \\ E-mail: cyntiapratiwi20@gmail.com
}

\begin{abstract}
ABSTRAK
Tujuan dari penelitian ini adalah untuk mengetahui: 1). Tingkat efektivitas program revitalisasi pasar di pasar Pohgading Kecamatan Denpasar Utara, 2). Kondisi pendapatan pedagang sebelum dan setelah program revitalisasi pasar tradisional di pasar Pohgading Kecamatan Denpasar Utara, 3). Kondisi pengelolaan pasar sebelum dan setelah program revitalisasi pasar tradisional di pasar Pohgading Kecamatan Denpasar Utara. Penelitian ini dilakukan di Pasar Desa Pakraman pohgading Kecamatan Denpasar Utara. Teknik analisis yang digunakan adalah analisis deskripsi dan uji beda dua rata-rata sampel berpasangan. Berdasarkan hasil analisis diperoleh kesimpulan bahwa tingkat keberhasilan program revitalisasi pasar tradisional tergolong cukup efektif dilihat dari variabel input tingkat efektifitasnya yaitu sebesar 73,25 (cukup efektif), variabel proses tingkat efektivitasnya yaitu 67,25 (cukup efektif) dan variabel output tingkat efektivitasnya yaitu 72,75 (cukup efektif). Terdapat peningkatan pendapatan pedagang setelah dilaksanakannya program revitalisasi pasar tradisional. Pengelolaan pasar lebih baik setelah program revitalisasi pasar tradisional.
\end{abstract}

Kata Kunci:efektivitas, revitalisasi, pasar tradisional, pendapatan pedagang, pengelolaan pasar

\begin{abstract}
The purpose of this study is to find out: 1). The level of effectiveness of the market revitalization program in the Pohgading market in North Denpasar District, 2). The income conditions of traders before and after the traditional market revitalization program in the Pohgading market in North Denpasar District, 3). Market management conditions before and after the traditional market revitalization program in the Pohgading market in North Denpasar District. This research was conducted at the Pasar Pakraman Pohgading Village, North Denpasar District. The analysis technique used is description analysis and different test two paired sample averages. Based on the analysis, it can be concluded that the success rate of the traditional market revitalization program is quite effective seen from the input variable effectiveness level of 73.25 (quite effective), the process variable effectiveness level is 67.25 (quite effective) and the output variable is 72,75 (quite effective). There is an increase in merchant income after the implementation of a traditional market revitalization program. Better market management after traditional market revitalization programs.
\end{abstract}

Keywords: effectiveness, revitalization, traditional markets, merchant income, market management 


\section{PENDAHULUAN}

Keberadaan pusat perdagangan merupakan salah satu indikator paling nyata terlihat pada kegiatan ekonomi masyarakat di suatu wilayah. Menurut bentuk fisik, perdagangan dibagi menjadi dua yaitu pasar tradisional dan pusat perbelanjaan modern (Ayuningsasi, 2010). Aktivitas yang terjadi di suatu pusat perdagangan seperti pasar tradisional merupakan salah satu sub sistem pusat perdagangan di suatu kota yang menjadi salah satu parameter yang dapat digunakan untuk mengetahui pertumbuhan dan dinamika ekonomi suatu kota (Kiik, 2006). Pasar merupakan kumpulan para penjual dan pembeli yang saling berinteraksi, saling tarik-menarik kemudian menciptakan harga barang di pasar. Seiring dengan perkembangan zaman dan semakin majunya teknologi pasar tidak saja sebagai tempat terjadinya transaksi jual-beli barang dan jasa bagi masyarakat yang ada disekitar pasar, lebih dari itu pasar telah dijadikan sebagai sarana penggerak roda perekonomian dalam skala besar (Mirah, 2013).

Keberadaan pasar mempunyai fungsi yang sangat penting, secara umum terdapat tiga fungsi utama pasar yaitu sebagai sarana distribusi, sebagai pembentuk harga, dan sebagai sarana promosi (Dwi, 2017). Pasar merupakan suatu wadah utama penjualan produk-produk yang dihasilkan oleh para pelaku ekonomi berskala kecil. Pasar merupakan tempat bagi mereka yang ingin memenuhi kebutuhannya, dimana uang dijadikan alat untuk bertransaksi guna memenuhi keinginan mereka dalam berbelanja barang atau jasa yang mereka butuhkan (Sudirmansyah, 2011). Keberadaan pasar ditengah-tengah masyarakat memiliki peran yang sangat penting karena di dalam pasar terdapat berbagai macam kebutuhan pokok, berupa bahan pangan maupun sandang yang dijual 
secara grosir maupun eceran. Berkaitan dengan pola konsumsi, sebagian besar masyarakat mengenal pasar tradisional sebagai salah satu tempat perbelanjaan untuk memenuhi kebutuhan hidupnya (Feinny dan Sifrit, 2015).

Menurut Menteri Perdagangan RI Gita Wirjawan (Handoyo, 2012), pasar harus dapat memenuhi fungsi strategisnya yaitu, memberikan kontribusi bagi pertumbuhan ekonomi, menciptakan lapangan kerja dan kesejahteraan masyarakat, Usaha Kecil dan Menengah (UKM), meningkatkan Pendapatan Asli Daerah (PAD), penguatan nilai sosial dan budaya Indonesia, serta menjadi penggerak pertumbuhan ekonomi suatu daerah. Defitri (2011) menyatakan bahwa Pendapatan Asli Daerah (PAD) melalui sumber-sumber PAD salah satunya berasal dari retribusi pelayanan pasar. Pasar memiliki kaitan erat dengan PAD, karena menjadi penunjang perekonomian daerah sehingga eksistensi pasar tradisional harus mendapatkan perhatian yang lebih intensif dari pemerintah daerah. Preffermann (2000) menyatakan para pedagang di pasar tradisional yang masuk dalam kategori sektor informal mampu menyumbangkan peluang kerja.

Sejalan dengan perkembangan masyarakat yang semakin pesat menuju ke arah modern, mulai banyak bermunculan pasar-pasar modern seperti hypermarket dan supermarket yang kehadirannya saat ini semakindilirik oleh masyarakat (Anom, 2017). Perkembangan pasar modern di Indonesia meningkat lebih pesat dibandingkan perkembangan pasar tradisional. Pasar modern tidak hanya dapat dijumpai di kota namun sudah merambah sampai ke pelosok desa. Kesamaan fungsi yang dimiliki pasar modern dan tradisional, telah menimbulkan persaingan antar keduannya (Juliarta, 2015). Konsumen yang berusia 15 sampai 30 tahun 
menghindari pasar tradisional dan lebih memilih supermarket (Ratih,2017). Konsumen lebih nyaman berbelanja di lingkungan toko yang memberikan kemudahan kepada konsumen ketika ingin membeli produk makanan segar (Rika Tarano dkk, 2014).

Ada beberapa ciri yang membedakan keduanya yaitu dilihat dari bangunan, tempat berjualan dan sistem jual beli yang dilakukan. Pasar modern biasanya memiliki bangunan yang megah dan permanen dengan fasilitas yang lebih nyaman dan aman dari pada di pasar tradisional. Pasar tradisional memiliki karakteristik tempat yang tidak terlalu luas, barang yang dijual tidak terlalu banyak macamnya, sistem manajemennya masih sederhana, tidak menawarkan kenyamanan berbelanja (Nelwan, 2017). Menurut Kupita dan Bintoro (2012: 46) ada beberapa ancaman yang muncul ketika pasar modern mendominasi dan pasar tradisional tidak dapat bersaing, yaitu (1) kecenderungan pembeli untuk datang ke pasar modern, karena letak minimarket, supermarket, dan hypermart yang strategis, sehingga memudahkan konsumen, (2) berkurangnya penerimaan potensial daerah yang berasal dari Usaha Kecil dan Menengah akibat bangkrutnya pasar tradisional, sedangkan pasar modern tidak berkontribusi signifikan pada penerimaan daerah, (3) dari sisi perbandingan jam kerja, di mana pasar modern beroperasi setiap hari selama 13 jam.

Citra negatif yang biasa ditemui di pasar tradisional merupakan salah satu penyebab beralihnya konsumen ke pasar modern, dimana kurang nyamannya konsumen dengan kondisi pasar tradisional yang sulit diubah. Disisi lain, pasar tradisioanl juga memiliki keunikan dan ciri khas yang berbeda-beda. Pasar 
tradisional di Bali contohnya memiliki keunikkan dan ciri khas yang jarang ditemui di pasar tradisional lainnya, dimana pasar di Bali menjual perlengkapan upacara keagamaan. Bali memiliki adat istiadat dan ritual keagamaan yang beragam, hal tersebut menyebabkan masyarakat di Bali tidak pernah lepas dari pasar tradisional.

Pasar tradisional umumnya memiliki kondisi lingkungan yang tidak nyaman seperti kotor, becek, bau dan biasanya terdiri dari los atau tenda. Pasar tradisional juga memiliki berbagai kelemahan yang telah menjadi karakter dasar yang sangat sulit diubah, mulai dari faktor tata ruang, tata letak, tampilan yang tidak sebaik dan sebagus pusat perbelanjaan modern, alokasi waktu operasional yang relatif terbatas, kurangnya teknologi yang digunakan, kualitas barang yang kurang baik, kurangnya promosi penjualan, rendahnya tingkat keamanan dan tempat parkir yang berantakan. Pasar tradisional memiliki limbah padat yang lebih banyak daripada pasar modern, namun pengelolaan limbah tersebut tidak dikelola dengan baik sehingga seringkali dapat memberikan efek negatif pada lingkungan pasar (Djoko M.Hartono, 2015).

Ditinjau dari keadaan non fisik berupa pengelolaan pasar, pengaturan kebijakan dan penyuluhan kepada para pedaganag pasar tradisional mengenai pemeliharaan pasar, serta kemampuan SDM para pedagang dan pengelolaan pasar secara teknis dan manajerial sangat terbatas (Lukman, dkk 2012). Manajemen pasar tidak mampu mengatasi masalah yang terjadi dan tidak mampu menciptakan pasar yang nyaman, aman dan bersih yang diinginkan masyarakat. Para pedagang juga kurang mengerti mengenai prilaku konsumen, kurangnya informasi dan 
pengetahuan yang dimiliki pedagang menyebabkan pedagang tidak mengetahui cepatnya perubahan terhadap selera konsumen yang selalu berubah-ubah dari waktu (Mirah, 2013). Pasar tradisional dikelola tanpa inovasi akan mengakibatkan pasar menjadi tidak nyaman dan kompetitif (Kasali, 2007).

Untuk mengantisipasi kemungkinan terjadinya dampak negatif bagi pelaku usaha kecil menengah, pemerintah telah mengatur beroperasinya pelaku-pelaku perdagangan melalui Peraturan Presiden Nomor 112 Tahun 2007 tentang Penataan dan Pembinaan Pasar Tradisional, Pusat Perbelanjaan dan Toko Modern, yang kemudian ditindaklanjuti dengan pedoman pelaksanaan dengan Peraturan Menteri Perdagangan nomor 53/M-Dag/Per/12/2008 tentang Pedoman Penataan dan Pembinaan Pasar Tradisional, Pusat Perbelanjaan dan Toko Modern. Faktor kepuasan konsumen dalam berbelanja di pasar tradisional haruslah sangat diperhatikan, apabila tidak ingin kalah saing dengan pasar modern (Anom, 2017). Perkembangan selera konsumen yang menginginkan tempat berbelanja dengan lingkungan yang bersih, nyaman, dengan harga yang relatif murah, dan mutu barang yang dapat dipertanggungjawabkan (Wahyono, 2017).

Revitalisasi merupakan suatu langkah yang harus dilakukan pasar tradisional apabila ingin tetap menjaga eksistensinya di tengan-tengah persaingan dengan pasar-pasar modern yang lebih diminati masyarakat. Banyaknya bermunculnya pasar-pasar modern dengan fasilitas yang memadai dapat mengurangi peran pasar tradisional (Dessy, 2013). Revitalisasi merupakan suatu cara untuk menguatkan dan menghidupkan kembali peran suatu wilayah atau kawasan yang mengalami penurunan eksistensi akibat perkembangan jaman 
(Danisworo, 2000). Upaya yang dilakukan untuk meningkatkan kembali kondisi pasar tradisional dapat berupa perbaikan keadaan fisik maupun non fisik. Dengan menyelaraskan pasar dengan lingkungannya sesuai tuntutan kebutuhan masyarakat dan peningkatan identitas kawasan (Aliyah, Setioko, \& Pradoto, Benghida, 2014). Terkait dengan pelaku ekonomi pasar tradisional, diharapkan revitalisasi ini dapat meningkatkan kesejahteraan pedagang (Dessy, 2013). Perbaikan dalam berbagai hal baik fisik maupun non fisik diharapkan mampu meningkatkan citra dan daya saing dari pasar tradisional sehingga kembali dilirik oleh konsumen dan mampu bersaing dari pasar modern (Feinny \& Sifrit, 2015).

Kota Denpasar sebagai Ibu Kota Provinsi Bali dan sebagai pusat aktivitas ekonomi dimana adanya pengaruh dari globalisasi, akan menyebabkan terjadinya pergeseran minat masyarakat untuk berkunjung ke pasar tradisional dan beralih ke pasar modern (Dwi, 2017). Revitalisai pasar tradisional ini sangat bermanfaat karena akan memberikan dampak yang nyata untuk pendapatan para pedagang yang ada didalamnya. Pemerintah harus menyikapi hal ini agar pasar tradisional ini bisa berkembang secara berkelanjutan dengan membuat berbagai program salah satunya yang sedang dijalankan saat ini adalah merevitalisasi pasar tradisional (Jerry et al, 2011). Menyikapi hal tersebut mendorong Pemerintah Kota Denpasar melakukan revitalisasi pasar tradisional yang merupakan wujud komitmen pemerintah di bidang ekonomi kerakyatan.

Di Kota Denpasar terdapat 51 pasar tradisional dan memiliki 10.187 orang pedagang. Data mengenai jumlah pasar tradisional dan jumlah pedagang pasar tradisional di Kota Denpasar secara lengkap disajikan pada Tabel 1. 
Tabel 1.

Jumlah Pasar dan Jumlah Pedagang Pada Pasar Tradisional di Kota Denpasar

\begin{tabular}{ccccc}
\hline A & Kota Denpasar & $\begin{array}{c}\text { Pasar Tradisional } \\
(\text { Unit) }\end{array}$ & $\begin{array}{c}\text { Jumlah Pedagang Pasar } \\
\text { Tradisional (Orang) }\end{array}$ \\
\hline & 1. & Denpasar Barat & 5 & 323 \\
2. & Denpasar Selatan & 16 & 1.214 \\
& 3. & Denpasar Timur & 7 & 471 \\
& 4. & Denpasar Utara & 6 & 660 \\
B & PD Pasar Kota Denpasar & 17 & 7.519 \\
& & Kota Denpasar & $\mathbf{5 1}$ & $\mathbf{1 0 . 1 8 7}$ \\
\hline
\end{tabular}

Sumber: PD. Pasar Pasar Kota Denpasar, 2019

Tabel 1 memperlihatkan bahwa PD Pasar Kota Denpasar memiliki pasar tradisional sebanyak 17 unit pasar dengan jumlah pedagang pasar tradisional sebanyak 7.519 jumlah pedagang. Kecamatan Denpasar Barat terdapat pasar tradisional sebanyak 5unit pasar dengan jumlah pedagang sebanyak 323, Kecamatan Denpasar Selatan terdapat 16 unit pasar tradisional dengan jumlah pedagang yang dimiliki sebanyak 1.214 pedagang, Kecamatan Denpasar Timur terdapat 7 unit pasar tradisional dengan jumlah pedaganag yang dimiliki sebanyak 471 pedagang dan Kecamatan Denpasar Utara terdapat 6 unit pasar tradisioal dengan jumlah pedagang yang dimiliki sebanyak 660 pedagang. Kota Denpasar memiliki 51 unit pasar tradisional dimana 17 unit pasar dikekola oleh PD. Pasar Kota Denpasar dan sisanya dikelola oleh Desa Pekraman. Pemerintah Kota Denpasar telah merevitalisasi enam pasar tradisional yang ada di Kota Denpasar. Untuk melihat data jumlah pasar tradisional yang sudah direvitalisasi dan dikelola oleh Desa Pekraman di Kota Denpasar disajikan pada Tabel 1. 
Tabel 2.

\section{Jumlah Pasar Tradisional Yang Sudah Direvitalisasi Di Kota Denpasar Tahun 2018}

\begin{tabular}{clc}
\hline No & Pasar Desa Adat & Jumlah Pedagang \\
\hline 1 & Pasar Agung & 353 \\
2 & Pasar Nyanggelan & 199 \\
3 & Pasar Pohgading & 201 \\
4 & Pasar Kerta Waringin Sari & 122 \\
5 & Pasar Padang Sambian & 183 \\
6 & Pasar Sudha Merta & 154 \\
\hline
\end{tabular}

Sumber:Kantor Badan Pemberdayaan Masyarakat dan Pemerintahan Desa, 2018

Tabel 2 menunjukan jumlah pedagang pada tiap-tiap pasar yang telah direvitalisasi. Pasar Agung memiliki jumlah pedagang sebanyak 353 orang pedagang, Pasar Nyanggelan memiliki jumlah pedagang sebanyak 199 pedagang, Pasar Pohgading memiliki jumlah pedagang sebanyak 201 jumlah pedagang, Pasar Kerta Waringin Sari memiliki jumlah pedagang sebanyak 122 pedagang, Pasar Padang Sambian memiliki jumlah pedagang sebanyak 183 pedagang, dan Pasar Sudha Merta memiliki jumlah pedagang sebanyak 154 pedagang. Revitalisasi tidak hanya memperbaiki sarana fisik semata namun revitalisasi merupakan konsep yang menyeluruh dari semua aspek dalam membenahi pasar tradisional yaitu memperbaiki sistem manajemen dan pemerdayaan pedagang.

Pasar Pohgading setelah dilaksanakannya program revitalisasi pasar yang dilakukan pemerintah Kota Denpasar menjadikannya pasar yang lebih bersih, sehat, dan nyamann bagi para pengunjung. Perkembangan Pasar Pohgading juga didukung dengan penambahan-penambahan los dan kios yang dapat digunakan para pedagang. Jumlah pedagang yang terdaftar pada pasar Pohgading dapat di lihat pada Tabel 3 . 
Tabel 3.

Jumlah Pedagang yang Terdaftar di Pasar Pohgading Denpasar Utara Setalah Program Revitalisasi Pasar Tradisional

\begin{tabular}{cll}
\hline No. & Tempat Berdagang & Jumlah Pedagang \\
\hline 1. & Los & 127 Pedagang \\
2. & Kios & 74 Pedagang \\
\hline & Jumlah & 201 pedagang \\
\hline
\end{tabular}

Sumber:PD Pasar Pohgading, 2018

Dari Tabel 3 menunjukkan daftar pedagang di pasar Pohgading setelah diadakannya program revitalisasi pasar, dimana jumlah pedagang yang menempati los sebanyak 127 pedagang dan menempati kios sebanyak 74 pedagang. Setelah direvitalisasi menyebabkan persaingan antar pedagang di pasar Pohgading karena adanya zonasi pedagang. Pedagang yang mendapatkan tempat berjualan paling pojok sangat jarang dikunjungi oleh konsumen.

Program revitalisasi pasar tradisional mempunyai tujuan untuk merubah wajah pasar tradisional menjadi lebih terstruktur, bersih dan nyaman, untuk mendorong kesadaran pedagang dalam hal kebersihan produk, kesehatan dan sanitasi, meningkatkan daya saing pasar rakyat, meningkatkan kesejahteraan para pedagang melalui peningkatan omzet, mendukung kelancaran logistik dan distribusi bahan kebutuhan masyarakat, meningkatkan kinerja dan kualitas pasar dan meningkatkan jumlah pengunjung, selain itu revitalisasi pasar tradisional memiliki tujuan untuk peningkatan vitalitas Kawasan (Lee, 2017).

Efektivitas merupakan pencapaian tujuan program. Dikatakan efektif apabila tepat sasaran atau mencapai target yang telah ditetapkan. Hidayat (1986) menjelaskan bahwa efektivitas adalah suatu ukuran yang menyatakan seberapa jauh target (kuantitas,kualitas dan waktu) telah tercapai. Program revitalisasi 
pasar dikatakan efektif apabila membawa pengaruh atau perubahan terhadap sasaran program, hal yang dimaksud adalah program membawa pengaruh positif terhadap perbaikan pasar dalam upaya mempertahankan eksistensi pasar tradisional. Efektivitas program pasar tradisional ini akan tercapai apabila adanya dukungan dari semua pihak terutama pengelola pasar dan pedagang di dalam aktivitas pasar tradisional. Efektivitas ditinjau dengan menggunakan variabel input, proses dan output (Ita Wulandari dan Meydinawathi, 2016).

Strategi lainnya yang dapat dilakukan agar tercapainya program revitalisasi pasar tradisional adalah pembenahan manajemen atau pengelolaan pasar. Mirah (2013) menyatakan bahwa rendahnya kinerja pengelolaan pasar juga disebebkan oleh rendahnya jumlah personil, rendahnya pendidikan dan kurangnya pelatihan terhadap petugas. Perbaikan kondisi non fisik seperti manajemen pengelolaan yang baik dan professional dengan SDM pengelola pasar yang berkualitas diharapkan mampu meningkatkan daya saing pasar tradisional, meningkatkan jumlah kunjungan konsumen untuk berbelanja di pasar tradisional, hal ini akan berpengaruh terhadap peningkatan pendapatan pedagang.

Menurut Made Suparta selaku kepala pengelola Pasar Desa Pakraman Pohgading, Pasar Pohgading mendapat bantuan dari dana Tugas Pembantuan (TP) kementerian perdagangan. Revitalisasi yang dilakukan pasar Pohgading melalui tiga tahap dimana pada tahun 2013 pasar Pohgading mendapat bantuan pertama kali untuk revitalisasi sebesar Rp. 500 juta rupiah, tahap kedua pada tahun 2015 mendapat dana bantuan sebesar Rp. 5 miliyar dan tahap ketiga pada tahun 2016 dengan bantuan dana sebesar Rp. 6 miliyar. Pasar Pohgading mendapat sertifikasi 
pasar SNI. Pasar Pohgading masuk dalam pasar tipe IV dari persyaratan dan ketentuan pasar SNI. Persyaratan ini meliputi jumlah pedagang yang kurang dari 250 orang, zonasi pedagang, ketersediaan ruang menyusui, pencegah kebakaran, pemilahan sampah, hingga kebersihan pasar. Menurut Watanabe (2015)konsep pembangunan yang telah dirancang dengan memberikan sentuhan pasar tradisional yang lebih modern, segar dan ramah mengadopsi manajemen pusat perbelanjaan modern yang memusatkan pada masalah kebersihan. Pasar tradisional dengan mengadopsi manajemen pasar modern diharapkan mampu mendorong minat belanja kalangan ibu rumah tangga untuk membeli kebutuhan sehari-hari.

Peraturan pemerintah No. 39 tahun 2006 tetang Tata Cara Pengendalian dan Evaluasi Pelaksanaan Rencana Pembangunan, dimana evaluasi diadakan dengan maksud untuk dapat mengetahui dengan pasti apakah pencapaian hasil, kemajuan, dan kedala yang terjadi dalam pelaksanaan rencana pembangunan dapat dinilai dan dipelajari untuk bisa diperbaiki pelaksanaan rencana pembangunan dimasa yang akan datang (Anom, 2015). Setiap program yang dibuat dan dilaksanakan oleh pemerintah wajib dilakukan evaluasi dan monitoring untuk menjamin pelaksanaan program sesuai dengan acuan dan rencana yang telah ditetapkan.

Berbagai citra buruk yang selama ini melekat di pasar tradisional berusaha dibenahi kembali. Tata kelola pasar yang menjadi titik lemah harus diperbaiki untuk menambah jumlah kunjungan konsumen di pasar tradisional (Adiyadnya,2015). Manajemen pengelolaan pasar yang tidak teratur serta 
infrastruktur yang tidak tertata merupakan salah satu penyebab utama dari kalahnya pasar tradisional dengan pasar modern. Mewujudkan pasar yang baik haruslah dikekola dengan manajemen yang terpadu dimana seluruh manajemen pasar menjadi satu. Pengelola pasar mempunyai tugas utama yaitu memberikan fasilitas yang berupa tempat atau lokasi berdagang bagi pedagang tradisional yang telah menyewa atau membeli kios (Hadiwiyono, 2011). Pembenahan kondisi fisik dan non fisik pasar tradisional, diharapkan mampu meningkatkan jumlah kunjungan konsumen ke pasar tradisional untuk berbelanja di pasar tradisional, hal ini akan berpengaruh terhadap pendapatan pedagang yang semakin meningkat (Dwi Setyadhi dan Desy, 2013).

Pendapatan pedagang merupakan suatu bentuk balas jasa yang diterima suatu pihak atas keikutsertaanya dalam proses produksi barang dan jasa. Sukirno (2000) mengungkapkan bahwa pendapatan individu merupakan pendapatan yang diterima seluruh rumah tangga dalam perekonomian dari pembayaran atas penggunaann faktor-faktor produksi yang dimilikinya dan dari sumber lain. Menurut Sanuharyo (1982), dilihat dari pemanfaatan tenaga kerja, pendapatan yang berasal dari balas jasa berupa upah atau gaji disebut dengan pendapatan tenaga kerja (Labour Income), sedangkan dari selain tenaga kerja disebut dengan pendapatan bukan tenaga kerja (Non Labour Income). Perbedaan antar pendapatan tenaga kerja dan pendapatan bukan tenaga kerja tidaklah selalu mudah dilakukan, ini disebabkan karena nilai output tertentu umumnya terjadi atas kerjasama antara faktor produksi lain karena itu, cara perhitungannya pun berbeda tergantung lapangan pekerjaannya. Bagi yang bekerja dan menerima balas jasa berupa upah 
atau gaji digunakan pendekatan pendapatan (income approach). Bagi yang bekerja sebagai pedagang, pendapatannya dihitung dengan melihat keuntungan yang diperolehnya. Bagi yang bekerja sebagai petani, pendapatannya dihitung dengan pendekatan produksi.

Pengertian revitalisasi yang ada dalam kamus besar bahasa Indonesia berarti proses, cara, dan perbuatan menghidupkan kembali suatu hal yang sebelumnya terberdaya. Revitalisasi adalah upaya untuk menghidupkan kembali suatu kawasan atau bagian kota yang dulunya pernah hidup, kemudian mengalami kemunduran (Juliarta, 2015). Di Indonesia hampir semua pasar tradisional masih bermasalah dengan keadaan internal mereka seperti manajemen pasar yang buruk, kurangnya pembenahan dalam struktur pasar dan masalah kebersiahan (Fransisca dkk, 2012). Pembenahan faktor produk dan terutama faktor tempat yang mengarah pada fasilitas pasar agar menjadi tempat belanja yang bercitra positif dan dapat berpengaruh kepada meningkatnya kualitas pelayanan publik (Anika dkk,2014). Menurut Dwinovanto (2013) revitalisasi merupakan suatu upaya untuk menghidupkan kembali suatu kawasan atau bagian kota yang dulunya pernah hidup, namun revitalisasi harus seperti sejarah, makna, serta keunikan dan citra lokasi. Membangun pasar tradisional yang baru merupakan salah satu cara merevitalisasi untuk menciptakan pasar tradisional dengan berbagai fungsi, seperti tempat berekreasi dan bersantai mengalami degradasi oleh perkembangan jaman. Keinginan pemerintah untuk merevitalisasi pasar adalah untuk meningkatkan pendapatan lokal (Prastyawan, 2015). Revitalisasi pasar tradisional dilaksanakan dengan melakukan pembenahan pasar tradisional secara 
menyeluruh, mulai dari pembenahan lingkungan fisik, manajemen pengelolaan pasar, hingga peningkatan kualitas SDM (Ayuningsasi, 2013). dampak revitalisasi dapat dilihat melalui energi, sosial, ekonomi dan ekologi (Kljajic, Andelkovic, \& Mujan, 2016).

Kerangka konseptual dalam penelitian ini menganalisis efektivitas program revitalisasi pasar tradisional dan dampaknya terhadap pendapatan pedagang dan pengelolaan pasar di Pasar Desa Pakraman Pohgading Kecamatan Denpasar utara. Efektivitas merupakan keberhasilan suatu hal, kegiatan, atau program apabila telah mencapai target yang direncakan dan disepakati sebelumnya. Program revitalisasi pasar dikatakan efektif apabila membawa pengaruh atau perubahan terhadap sasaran program, hal yang dimaksud adalah program membawa pengaruh positif terhadap perbaikan pasar dalam upaya mempertahankan eksistensi pasar tradisional. Hal ini dibuktikan oleh penelitian Anom (2017) menyatakan dalam penelitiannya bahwa tingkat keberhasilan program revitalisasi pasar tradisional dilihat dari variabel input, proses dan output tergolong efektif. Penelitian yang dilakukan oleh Mirah (2013) dengan judul Efektivitas dan Dampak Program Revitalisasi Pasar Tradisonal di Pasar Agung Peninjoan diperoleh hasil bahwa tingkat efektivitas program revitalisasi pasar tradisional berjalan cukup efektif yaitu sebesar 71,79 persen. Dalam penelitian yang dilakukan oleh Putra (2017) menyatakan bahwa tingkat efektivitas revitalisasi pasar tradisional di Kota Denpasar cukup efektif yaitu sebesar 72,82 persen. 
Berbagai citra buruk yang selama ini melekat di pasar tradisional berusaha dibenahi kembali, Pernyataan tersebut yang mendorong pemerintah Kota Denpasar melakukan revitalisasi pasar tradisional yang merupakan wujud komitmen pemerintah di bidang ekonomi kerakyatan.Pembenahan kondisi fisik pasar tradisional agar menjadi lebih bersih dan nyaman, diharapkan mampu meningkatkan jumlah kunjungan konsumen ke pasar tradisional untuk berbelanja di pasar tradisional sehingga pendapatan pedagang meningkat. Mulai dari menjaga area berjualan agar selalu bersih, tersedianya tempat sampah di tiap kios maupun los, dan lain sebagainya. Pembenahan area parkir juga menjadi salah satu aspek pendukung. Kasali (2007) mengatakan didalam era persaingan seperti sekarang pasar tradisional yang dikelola tanpa diiringi oleh inovasi akan menyebabkan pasar menjadi tidak kompetitif dan tidak nyaman. Putrawan (2014) dalam penelitiannya menyatakan menyatakan bahwa revitalisasi berpengaruh positif terhadap pendapatan pedagang pada pasar kumbasari. Juliarta (2015) menyatakan bahwa revitalisasi berpengaruh positif terhadap pendapatan pedagang pada pasar nyanggelan panjer. Dwi (2017) menyatakan bahwa revitalisasi pasar tradisional berpengaruh positif dan signifikan terhadap pendapatan pedagang pasar di Kota Denpasar.

Perbaikan kondisi non fisik seperti manajemen pengelolaan yang baik dan professional dengan SDM pengelola pasar yang berkualitas diharapkan mampu meningkatkan daya saing pasar tradisional, meningkatkan jumlah kunjungan konsumen untuk berbelanja di pasar tradisional, hal ini akan berpengaruh terhadap peningkatan pendapatan pedagang. Demi mewujudkan pasar yang bersih, aman 
dan nyaman, pedagang dan pengelola pasar harus konsisten untuk menjaga kenyamanan pasar tradisional. Program revitalisasi merupakan solusi dimana pasar tradisional siap berbenah diri dari segi pengelolaan pasar dan kondisi fisik sehingga mampu menyaingi pasar modern. Dalam penelitian Juliarta (2015) program revitalisasi pasar tradisioanl memberi dampak positif terhadap peningkatan pengelolaan pasar.

\section{METODE PENELITIAN}

Penelitian dilakukan di Pasar Desa Pakraman Pohgading Ubung Kaja Kecamatan Denpasar Utara. Pasar Pohgading dipilih karena Pasar Pohgading salah satu pasar yang sudah direvitalisasi dan menjadi pasar yang sudah diverifikasi SNI yang diresmikan sebagai pusat perekonomian terbesar di Kota Denpasar. Terlebih lagi pasar Pohgading yang merupakan pasar adat menjadi daya tarik masyarakat lokal setelah adanya program revitalisasi pasar. Pasar Pohgading ini direvitalisasi melalui 3 tahap yaitu pada tahun 2013, tahun 2015 dan tahun 2016. Selain itu, di pasar Pohgading belum ada informasi mengenai keefektivitasan program revitalisasi pasar.

Dalan penelitian ini populasinya meliputi keseluruhan pedagang di Pasar Pohgading karena pedagang yang dirasa paling mengetahui perubahan yang terjadi setelah diadakannya program revitalisasi pasar tradisional. Berdasarkan data yang telah diperoleh populasi dari pedagang di Pasar Pohgading adalah sebanyak 201 orang. Teknik sampling yang digunakan dalam penelitian ini adalah 
probability random sampling. Jumlah sampel dalam penelitian ini ditentukan berdasarkan pendekatan Slovin dengan rumus sebagai berikut:

$\mathrm{n}=\frac{N}{1+N e^{2}}$

Keterangan :

n: ukuran sampel

$\mathrm{N}$ : ukuran populasi

e: nilai kritis $(10 \%)$

Dengan rumus tersebut dapat dihitung jumlah sampel pada penelitian ini. dengan jumlah populasi pedagang Pasar Desa Pakraman Pohgading adalah 201 orang, maka perhitungan sampelnya adalah sebagai berikut :

$\mathrm{n}=\frac{201}{1+\left(201 \times 0,1^{2}\right)}$

$\mathrm{n}=\frac{201}{1+2,01}$

$\mathrm{n}=66,77$ (dibulatkan menjadi 67)

berdasarkan perhitungan diatas, maka jumlah sampel yang akan diambil sebanyak 68 sampel (pedagang). Agar populasi dapat merata secara utuh, maka penarikan sampel pada masing-masing lokasi usaha ditentukan sebagai berikut :

$$
\begin{aligned}
& \text { Los }=\frac{127}{201} \times 67=42,33=42 \\
& \text { Kios }=\frac{74}{201} \times 67=25
\end{aligned}
$$


Untuk mengetahui efektivitas program revitalisasi di Pasar Pohgading digunakan teknik analisis deskriptif dengan memaknai perhitungan tingkat efektivitas program yang dihitung dengan rumus sebagai berikut.

Efektivitas $=\frac{\text { Realisasi }}{\text { Target }} \times 100$

Keterangan:

Efektivitas =Ukuran berhasil atau tidaknya Program Revitalisasi Pasar Tradisional (\%) - Realisasi = Pencapaian pelaksanaan program

Target $=$ Seluruh anggota kelompok yang mengikuti program

Pengukuran tingkat efektivitas dilakukan pada variabel input, proses, output dan serta digunakan statistik deskriptif rata-ratanya yang dilakukan pada masing-masing indikator. Setelah mendapatkan tingkat efektivitas dari masingmasing indikator pada variabel input, proses, output, selanjutnya dilakukan pengklasifikasian sesuai dengan kriteria dari Litbang Depdagri 1991.

Untuk menganalisis dampak program revitalisasi pasar terhadap pendapatan pedagang dan pengelolaan pasar, dilakukan pengujian statistic yaitu uji beda dua rata-rata sampel berpasangan.

\section{HASIL DAN PEMBAHASAN}

Persepsi responden mengenai kegiatan sosialisasi program revitalisasi pasar tradisional menunjukan nilai rata-rata sebesar 2,98 bila dibandingkan dengan nilai pencapaian hasil maksimum sebesar 4 maka pencapaian efektivitas dari kegiatan sosialisasi program sebesar 74,05 persen (cukup efektif).

Persepsi responden mengenai tingkat ketepatan sasaran menunjukan nilai rata-rata sebesar 2,83, bila dibandingkan dengan nilai pencapaian hasil maksimal 
sebesar 4 maka pencapaian efektivitas dari tingkat ketepatan sasaran sebesar 70,75 persen (cukup efektif).

Persepsi responden mengenai tujuan program menunjukan nilai rata-rata sebesar 2,97, bila dibandingkan dengan nilai pencapaian hasil maksimal sebesar 4 maka pencapaian efektivitas dari tujuan program sebesar 74,25 persen (cukup efektif).

Persepsi responden mengenai tingkat daya terima responden terhadap proses revitalisasi menunjukan nilai rata-rata sebesar 2,94 persen, bila dibandingkan dengan nilai pencapaian hasil maksimal sebesar 4 maka pencapaian efektivitas dari daya terima responden terhadap proses revitalisasi sebesar 73,05 persen (cukup efektif).

Berdasarkan data tersebut, efektivitas pelaksanaan program revitalisasi pasar tradisional pada variabel input, dapat di uraikan sebagai berikiut.

$$
\begin{aligned}
\text { Efektivitas Program } & =\frac{\text { Realisasi }}{\text { Target }} \times 100 \% \\
\text { Efektivitas program } & =\frac{2,93}{4} \times 100 \\
& =73,25 \text { (cukup efektif) }
\end{aligned}
$$

Persepsi responden mengenai tingkat daya terima petugas terhadap keluhan menunjukan nilai rata-rata sebesar 2,71, bila dibandingkan dengan nilai pencapaian hasil maksimal sebesar 4 maka pencapaian efektivitas dari tingkat daya terima petugas terhadap keluhan sebesar 67,75 persen (cukup efektif).

Persepsi responden mengenai tingkat kecepatan respon petugas terhadap keluhan menunjukan nilai rata-rata sebesar 2,55, bila dibandingkan dengan nilai 
pecapaian hasil maksimal sebesar 4 maka pencapaian efektivkitas dari tingkat kecepatan respon petugas terhadap keluhan sebesar 63,75 (cukup efektif).

Persepsi responden mengenai tingkat monitoring menunjukan nilai rata-rata sebesar 2,82, bila dibandingkan dengan nilai pencapaian hasil maksimal sebesar 4 maka pencapaian efektivitas dari tingkat monitoring sebesar 70,5 persen (cukup efektif).

Berdasarkan data tersebut, efektivitas pelaksanaan Program Revitalisasi Pasar Tradisional pada variabel proses, dapat diuraikan sebagai berikut.

$$
\begin{aligned}
\text { Efektivitas Program } & =\frac{\text { Realisasi }}{\text { Target }} \times 100 \% \\
\text { Efektivitas program } & =\frac{2,69}{4} \times 100 \\
& =67,25 \text { (cukup efektif) }
\end{aligned}
$$

Persepsi pedagang mengenai zonasi pedagang menunjukan nila rata-rata sebesar 2,73 persen bila dibandingkan dengan nilai pencapaian hasil maksimal sebesar 4 maka pencapaian efektivitas dari zonasi pedagang sebesar 68,25 persen (cukup efektif).

Persepsi respinden mengenai manajemen pasar menunjukan nilai rata-rata sebesar 2,83 persen bila dibandingkan dengan nilai pencapaian hasil maksimal sebesar 4 maka pencapaian efektivitas dari manajemen pasar sebesar 70,75 persen (cukup efektif).

Persepsi respinden mengenai pemeliharaan sarana pasar menunjukan nilai rata-rata sebesar 2,92 persen bila dibandingkan dengan nilai pencapaian hasil maksimal sebesar 4 maka pencapaian efektivitas dari pemeliharaan sarana pasar sebesar 73,00 persen (cukup efektif). 
Persepsi responden mengenai kebersihan pasar menunjukan nilai rata-rata sebesar 2,98 persen bila dibandingkan dengan nilai pencapaian hasil maksimal sebesar 4 maka pencapaian efektivitas dari kebersihan pasar sebesar 74,05 persen (cukup efektif).

Persepsi responden mengenai keamanan pasar menunjukan nilai rata-rata sebesar 2,95 persen bila dibandingkan dengan nilai pencapaian hasil maksimal sebesar 4 maka pencapaian efektivitas dari keamanan pasar sebesar 73,75 persen (cukup efektif).

Persepsi responden mengenai kenyamanan pasar menunjukan nilai rata-rata sebesar 2,95 persen bila dibandingkan dengan nilai pencapaian hasil maksimal sebesar 4 maka pencapaian efektivitas dari kenyamanan pasar sebesar 73,75 persen (cukup efektif).

Persepsi responden mengenai keindahan pasar menunjukan nilai rata-rata sebesar 2,97 persen bila dibandingkan dengan nilai pencapaian hasil maksimal sebesar 4 maka pencapaian efektivitas dari keindahan pasar sebesar 74,25 persen (cukup efektif).

Persepsi responden mengenai kerapian pasar menunjukan nilai rata-rata sebesar 2,97 persen bila dibandingkan dengan nilai pencapaian hasil maksimal sebesar 4 maka pencapaian efektivitas dari kerapian pasar sebesar 74,25 persen (cukup efektif).

Berdasarkan data tersebut, efektivitas pelaksanaan program revitalisasi pasar tradisional pada variabel output, dapat diuraikan sebagai berikut.

Efektivitas Program $=\frac{\text { Realisasi }}{\text { Target }} \times 100 \%$ 


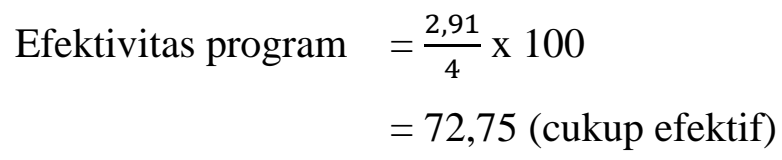

Berdasarkan hasil pengolahan data mengenai dampak revitalisasi pasar tradisional terhadap pendapatan pedagang di pasar Desa Pakraman Pohgading dengan menggunakan uji t didapat bahwa nilai $t_{\text {hitung }}$ yaitu $347,93>$ nilai $t_{\text {tabel }}$ yaitu 1,67hal ini berarti dampak program revitalisasi berdampak positif dan signifikan terhadap pendapatan pedagang di pasar Desa Pakraman Pohgading. penelitian yang dilakukan oleh Putra (2017) menyatakan bahwa revitalisasi pasar tradisional berpengaruh positif dan signifikan terhadap pendapatan pedagang pasar di Kota Denpasar.

Berdasarkan hasil pengolahan data mengenai dampak program revitalisasi pasar tradisional terhadap pengelolaan pasar di pasar Desa Pakraman Pohgading dengan metode Wilcoxon, diperoleh nilai Asymp.Sig.(2-tailed) 0,000 lebih rendah dengan 0,05, hal ini berarti dampak program revitalisasi pasar tradisional berdampak positif dan signifikan terhadap pengelolaan pasar di pasar Desa Pakraman Pohgading. Penelitian ini sejalan dengan penelitian yang dilakukan oleh Juliarta (2015) program revitalisasi pasar tradisioanl memberi dampak positif terhadap peningkatan pengelolaan pasar.

Efektivitas mencerminkan keberhasilan kinerja suatu program dalam mencapai tujuan yang telah ditetapkan. Program revitalisasi pasar dikatakan efektif apabila membawa pengaruh atau perubahan terhadap sasaran program, hal yang dimaksud adalah program membawa pengaruh positif terhadap perbaikan pasar dalam upaya mempertahankan eksistensi pasar tradisional. Hasil penelitian ini menunjukkan efektifitas pada pasar Desa Pakraman Pohgading cukup efektif 
hal ini mengandung implikasi bahwa program pemerintah dalam mengubah citra buruk pasar teralisasikan cukup efektif di pasar Desa Pakraman Pohgading.

Revitalisasi yang dilakukan yaitu revitalisasi kondisi fisik pasar tradisional agar menjadi lebih bersih dan nyaman, yang diharapkan mampu meningkatkan jumlah kunjungan konsumen ke pasar tradisional untuk berbelanja di pasar tradisional sehingga pendapatan pedagang meningkat. Hasil penelitian ini menunjukan bahwa program revitalisasi berdampak pada peningkatan pendapatan pedagang. Hal ini mengandung implikasi bila kondisi pasar yang nyaman dan aman akan meningkatkan jumlah kunjungan sehingga pendapatan pedagang meningkat.

Perbaikan kondisi non fisik seperti manajemen pengelolaan yang baik dan professional dengan SDM pengelola pasar yang berkualitas diharapkan mampu meningkatkan daya saing pasar tradisional, meningkatkan jumlah kunjungan konsumen untuk berbelanja di pasar tradisional, hal ini akan berpengaruh terhadap peningkatan pendapatan pedagang. Hasil penelitian ini menunjukan bahwa program revitalisasi berdampak pada pengelolaan pasar di pasar Desa Pakraman Pohgading, hal ini mengandung implikasi bahwa pengelolaan pasar yang baik akan meneningkatkan jumlah kunjungan yang akan berdampak pada pendapatan pedagang. 


\section{SIMPULAN}

Tingkat efektivitas pelaksanaan program revitalisasi pasar tradisional di Pasar Desa Pakraman Pohgading tergolong berjalan cukup berhasil, hal ini dapat dilihat dari rata-rata efektivitas dari variabel input, proses dan output yang memperoleh hasil yang cukup efektif.Program revitalisasi pasar tradisional memberikan dampak yang positif dan signifikan terhadap peningkatan pendapatan pedagang di Pasar Desa Pakraman Pohgading.Program revitalisasi pasar tradisional memberikan dampak positif dan signifikan terhadap peningkatan pengelolaan pasar di Pasar Desa Pakraman Pohgading.

Dari segi input, pedagang sudah tahu pasti tujuan dari program revitalisasi yang dilakukan pemerintah, untuk kedepannya agar pedagang tetap menjaga citra baik pasar karena revitalisasi pasar akan berjalan dengan baik apabila adanya dukungan dari semua pihak terutama pedagang di dalam melalukan aktivitas berjualan.

Dari segi proses, disarankan agar petugas lebih dapat meningkatkan pelayanan dan kecepatan respon terhadap berbagai keluhan yang disampaikan pedagang karena masih terdapat pedagang yang merasa pelayanan dan kecepatan respon petugas masih buruk.

Dari segi output, revitalisasi pasar di pasar Pohgading terbilang cukup efektif, kedepannya diharapkan para pedagang untuk tetap menjaga kebersihan agar pengunjung merasa nyaman dan untuk manajemen pasar diharapkan terus melalukan evaluasi agar kebersihan dan kerapian pasar tetap terjaga. 
Peningkatan pendapatan pedagang secara keseluruahan dapat diakatakan meningkat, namun masih terdapat pedagang yang mengalami penurunan pendapatan. Zonasi pedagang yang kurang strategis membuat pedagang kurang terlihat oleh konsumen, sebaiknya pedagang meningkatkan pelayanan dan kualitas produk sehingga membuat konsumen tertarik untuk berkunjung dan membeli produk.

Pengelolaan pasar di pasar Desa Pakraman Pohgading kini sudah jauh lebih baik dan lebih terstruktur organisasi pasarnya dibandingkan sebelum revitalisasi, tetapi dalam kegiatannya masih sering terjadi misskomunikasi antara petugas pengelola pasar. Letak peran koordinator masing-masing petugas perlu untuk mengkoordinir bawahannya sehingga dapat secara maksimal menanggapi apa saja keluhan dan permasalahan yang dialami oleh pedagang maupun konsumen.

\section{REFERENSI}

Adiyadnya, Made Santana Putra. 2015. Analisis Tingkat evektifitas dan Daya Saing Program Revitalisasi Pasar Tradisional di Pasar Agung peninjoan Peguyangan Kangin. Jurnal Piramida. Avaliabel at: ejurnal.unud.ac.id/.

Aliyah, I., Setioko, B., \& Pradoto, W. (2014). Traditional Market Revitalization as an Urban Catalyst in the City of Surakarta. Paper Presented at the International Conference on engineering and Technology Development (ICETD)

Anika Sunaryo Putri, Abdul Hakim dan Farida Nurani. 2014. The Availability of Traditional Market's Facility and its Effect on Quality of Public Service (Study at Perak Traditional Market in Jombang). Jurnal Administrasi Publik (JAP), 2 (2) pp:287-293.

Anom Arimbawa, I Gusti Ngurah Agung. 2017. Analisis Efektifitas Program Revitalisasi Pasar Tradisional di Pasar Desa Adat Intaran Sanur. Jurnal Piramida.8(1) h:22-23. 
Ayuningsasi, Anak Agung Ketut. 2010. Analisis Pendapatan Pedagang Sebelum dan Sesudah Program Revitalisasi Pasar Tradisional di Kota Denpasar (Studi Kasus Pasar Sudha Merta Desa Sidakarya. Jurnal Piramida. 7 (1) h:2-4.

2013. analisis faktor penentu referensi konsumen dalam berbelanja ke pasar tradisional di kota Denpasar : analisis faktor. Jurnal Ekonomi Kuantitatif Terapan. 6 (1) h:42.

Benghida, D (2014). The Urban Identity Recovery in Seoul: The Case of the Outdoor Markets. Paper presented at the $13^{\text {th }}$ Docomomo Internaational Conference Seoul: Expansion and conflict.

Danisworo, Mohammad \& Widjaja Martokusumo. 2000. Revitalisasi Kawasan Kota Sebuah Catatan dalam Pengembangan dan Pemanfaatan Kawasan Kota. Diakses dari www.urdi.org (urban and reginal development institute, 2000).

Defitri, Siska Yulia. 2011. Pengaruh Retribusi Pelayanan Pasar terhadap Retribusi Daerah Sebagai Sumber Pendapatan Asli Daerah Kota Solok. Jurnal. Jurusan Akuntansi UMMY.

Dessy Febriyanty. 2013. Model of Role Strengthening of Traditional Market Based on Sosial Capital in Indonesia. Study Case Beringharjo Market, Jogjakarta.Journal of Economics and Sustanable Development. 4, pp:155-156.

Djoko M. Hartono, Gabriel Andari Kristanto, Syaiful Amin. 2015. Potential Reduction of Solid Waste Generated from Traditional and Modern Markets.International Journal of Technology. 5 pp: 838-846.

Dwi Perwira Putra, I Kadek . 2017. Efektifitas dan Dampak Revitalisasi Pasaar Tradisional Terhadap Jumlah Kunjungan, Pendapatan Pedagang dan Pendapatan Pasar di Kota Denpasar. Avaliabel at: ejurnal.unud.ac.id/

Dwi Setyadhi Mustika, Made dan Desy Apriliani, Putu. 2013. analisis faktorfaktor yang Mempengaruhi Kebertahanan Pedagang Kuliner tradisional di Kabupaten Klungkung. Jurnal Ekonomi Kuantitatif Terapan. 6 (2) $\mathrm{h}: 120$

F.Feinny Lumihi dan Sifrit S.Pangemanan. 2015. The Influence of Firms's Service Dissatisfaction and Consumer Consideration on Consumer Switching Behavior From Traditional Market to Modern Market.Journal EMBA. 3 pp:252-260.

Fransisca Yaningwati, Achmad Fauzi DH, Susilowati. 2012. The Impact of Hypermarket Existence on The Tradisional Market Trader, Journal of Basic and Applied Scientific Research, 2 (8) pp:7966-7967. 
Hadiwiyono. 2011. Analisis Kinerja Pasar Tradisional di Era Persaingan Global di Kota Bogor. Skripsi Dapertemen Ilmu Ekonomi Fakultas Ekonomi dan Manajemen Institut Pernanian Bogor.

Handoyo, Eko.2012. Kontribusi Modal Sosial Dalam Meningkatkan Kesejahteraan Pedagang Kaki Lima Pasca Relokasi.Unnes Jurnal.

Hidayat. 1986. Teori Efektifitas Dalam Kinerja Karyawan. Yogyakarta:Gajah Mada University Press.

Ita Wulandari, Ni Luh Gede dan Meydinawathi, Luh Gde. 2016. Apakah Pasar Modern Menurunkan Pendapatan Pedagang di Pasar Tradisional? (Analisis Binary Logistik). Jurnal Ekonomi Kuantitatif Terapan. 9 (2) $\mathrm{h}: 159-160$.

Jerry J. Sweet Ph.D, Dawn Giuffre Meyer, Nathaniel W. Nelson \& Paul J. Moberg. 2011. The Ten/Aacn 2010 "Salary Survey". Professional Practices, Beliefs, And Incomes Of U.S. Neuropsychologists. Bulletin Of Indonesian Economic Studies, 25 (1) pp:12-61.

Juliarta, I Made Guna. 2015. Analisis Efektivitas Program Revitalisasi Pasar Tradisional dan Dampaknya terhadap Pengelolaan Pasar, Jumlah Pengunjung dan Pendapatan Pedagang Pasar (Studi Pasar Nyanggelan Desa Pekraman Panjer) Jurnal Piramida. Avaliabel at: ejurnal.unud.ac.id/

Kantor Pasar Desa Pakraman Pohgading. 2018. Data Pedagang Pasar, Denpasar.

Kasali, Renald 2007. Manajemen Periklanan : Konsep dan Aplikasinya, Jakarta Pustaka Utama Grafiti.

Kiik, V. M (2006) Kajian Faktor-faktor yang Mempengaruhi tidak Optimalnya Fungsi Pasar Tradisional Fatubenoo Kecamatan Kota Atambua Kabupaten Belu (Program Pasca Sarjana), Universitas Diponegoro. UNDIP Jurnal.

Kurniawan, Deny. 2008. Uji t berpasangan (paired t-test). Diakses dari http://ineddeni.files.wordpress.com/2008/03/uji-t-berpasangan.pdf.

Kljajic, M., Andelkovic, A. S., \& Mujan, I. 2016. Assessment of Revelence of Different Effect in Energy Infrastructure Revitalization in NonResidential Buildings. Journal Energy and Buildings.

Kupita, dan Bintaro. 2012. Implementasi Kebijakan Zonasi Pasar Tradisional dan Pasar Modern (studi di Kabupaten Purbalingga) Jurnal Dinamika Hukum, vol. 12 No. 1 Januari 2012.

Lee, Sungkyun. 2017. A Traditional Market Decline and Revitalization in Korea improving the Iksan Jungang Traditional Market. Bulletin Of Indonesian Economic Studies. 
Litbang Depdagri. 1991. Pengukuran Kemampuan Daerah Tingkat II Dalam Rangka Pelaksanaan Otonomi Nyata dan Bertanggungjawab. Jakarta

Lukman Muslimin, Fibria Indiati, dan Tjahya Widayanti. 2012. Kajian Model Pengembangan Pasar Tradisional. Buletin Ilmiah, H:1-44.

Mirah Pradnya Paramita, Anak Agung. 2013. Efektivitas dan Dampak Program Revitalisasi Pasar Tradisional di Pasar Agung Peninjoan. Jurnal Piramida. Avaliabel at: ejurnal.unud.ac.id/.

Nelwan, Jovan Wiradhana, S.L.H.V. Joyce Lapian, Farlane S. Rumokoy. 2017. The Existence of Traditional Market Toward Modern Market In Tohohon City.Jurnal EMBA.

Pemerintah Republik Indonesia. 2007. Peraturan Presiden Republik Indonesia Nomor 112 Tahun 2007 Tentang Penataan dan Pembinaan Pasar Tradisional, Pusat Perbelanjaan dan Toko Modern, Jakarta

Prastyawan, Agus, Agus Suryono, M.saleh Soeaidy, Khairul Muluk. 2015. Revitalization of Traditiona Market into a Modern Market in the Perspective of Local Governance Theory. IOSR Journal Of Humanities And Social Science (IOSR-JHSS).

Preffermann, Guy. 2000. Path Out of Poverty. The Role of Private Enterprise in Developing Countries. Washington, D.C. : International Finance Cooperation.

Putrawan, Eka. 2014. Persepsi Pedagang dan Dampak Program Revitalisasi Pasar Terhadap Tingkat Kunjungan, Pendapatan Pedagang dan Pendapatan Pasar di Pasar Kumbasari Denpasar. E-jurnal EP.

Ratih Kusuma Dewi, Ni Made, Sukadana, I Wayan dan Ayuningsasi, Anak Agung Ketut. 2017. Pilihan Tempat Belanja Masyarakat Perkotaan Dan Implikasinya Pada Peternak Ayam Petelur Di Perdesaan. Jurnal Ekonomi Kuantitatif Terapan.10 (2) h: 217-229.

Rika Teranoa, Rafidah Yahyan, Zainalabidin Mohameda dan Sahbani Bin Saimina. 2014. Consumers Shopping Preferences For Retail Format Choice Between Modern and Traditional Retails in Malaysia. Journal of Food Products Marketing. 20 pp:188.

R. Dimas Dwinovanto Putra dan Bambang Rudito.2013. Community Development Planning Of Pt Elva Primandiri's Revitalization Of Limbangan Traditional Market Project. Journal of Buseness and Management. 3 (1) pp 81-88.

Sanuharyo, Bambang. 1982. Pendapatan dan Pengeluaran Rumah Tangga Pegawai Golongan Rendah di Perumnas Klender dalam Mulyanto Sumardi dan Han Dieter-Evers. Kemiskinan dan Kebutuhan Pokok. Jakarta: Rajawali Press. 
Sudirmansyah, 2011. Pengertian dan Jenis-jenis Pasar. Diakses dari http://www.sudirmansyah.com/artikel-ekonomi/pengertian-dan-jenis-jenispasar.html.

Sukirno, Sadono. 2000. Makroekonomi Teori Pengantar, Jakarta : PT. Raharja Grafindo Persada.

Wahyono, budi. 2017. Analisis faktor-faktor yang mempengaruhi pendapatan pedagang di pasar Bantul Kabupaten Bantul. Jurnal pendidikan dan ekonomi.

Watanabe, Hiroaki Richard.2015. The Struggle For Revitalization by Japanese Labour Unions: Worker Organising after Labour-Market Deregulation.Bulletin Of Indonesian Economic Studies.

Wyoliffe Timotius Heryendi. 2013. Efektivitas Program Usaha Peningkatan Pendapatan Keluarga sejahtera (UPPK) di Kecamatan Denpasar Barat. Jurnal Ekonomi Kuantitatif Terapan. 6 (2) h:80. 